\title{
GUEST EDITOR'S NOTE: CHOMSKY 90
}

This special issue of Acta Linguistica Academica pays tribute to the significance of Noam Chomsky's work in linguistics and cognitive science and wishes to congratulate him on his 90th birthday.

On May 10, 2018 István Kenesei organized the workshop Chomsky 90: konferencia az idén 90 éves Noam Chomsky hatásáról [Chomsky 90: a workshop about the impact of Chomsky, who turns 90 this year] as part of the 189th General Assembly of the Hungarian Academy of Sciences. This conference featured talks about Chomsky's impact on linguistics, language acquisition, psychology, philosophy and evolutionary biology to a general audience. The written versions of the talks, supplemented with articles about Chomsky's influence on other fields such as media and politics, appeared in Kenesei (2019).

While this collection was in production, István Kenesei suggested that it would be useful to celebrate the round birthday with an English volume as well. This is when the idea of this special issue was born. For this issue, we had a narrower focus than the Hungarian volume and invited contributions on how Chomsky's work affected linguistics and cognitive science. The papers provide broad overviews of particular areas of study and were meant to be accessible for advanced MA and PhD students as well as linguists working in other fields.

My own contribution Foundations of generative linguistics rebuts the popular view that Chomsky's main contribution to linguistics is the introduction of transformations. The paper names (i) the change in the object of study (from E-language to I-language) and (ii) the attribution of a central role to the child's linguistic abilities as the two chief novel aspects of generative grammar. I clarify three further recurrent misunderstandings about generative grammar and summarize some of the main empirical results of generative syntax.

Michael Brody's article Some biolinguistic remarks identifies two main contributions of Chomsky to linguistics: the legitimation of abstract theoretical work in the field and the establishment of a long-term research paradigm with the poverty of the stimulus argument. He also discusses recent takes on the evolution of the language faculty (a topic which became 
of central importance with Hauser et al. 2002), and sketches a proposal about what is the uniquely human component of language.

David Lightfoot's paper Chomsky's I-languages: Rethinking catastrophic changes discusses the profound effect of Chomsky's distinction between E-language and I-language for diachronic linguistics and the theory of language change. On the traditional view, languages change slowly and gradually. Lightfoot argues that with the separation of E-language and I-language, there is no object "English" which is transmitted from one generation to another, instead, each child constructs its own individual, biological I-language. This, in turn, predicts the possibility of catastrophic changes such as the one argued for English in Emonds \& Faarlund (2014).

In The impact of generative linguistics on psychology: Language acquisition, a paradigm example, Caterina Marino and Judit Gervain survey the evidence that has accumulated for Chomsky's proposal that language has biological roots. They then discuss how the biologically based account of language acquisition spurred research into new empirical domains (studies of prelinguistic infants and perception as well as comparative work on humans and non-human animals) and allowed the independently developed field of neuroimaging to inform language theory. The Authors also review different bootstrapping hypotheses that address the linking problem, i.e., the issue of how children start the task of learning their mother-tongue.

Csaba Pléh discusses how Chomsky's input shaped modern cognitive science in The inspirational role of Chomsky in the cognitive turn. He reviews how Chomsky had a pivotal role in the decline of behaviorism and the birth of modern experimental psycholinguistics, and identifies seven key components in Chomsky's work which inspired a rich body of research in psychology: mentalism, theory theories, the centrality of form and sequential thought, a computational theory of mind, innatism and human freedom.

In the closing paper of this issue Marcel den Dikken reviews Syntactic Structures after 60 years (ed. by Hornstein et al.). This latest edition of Chomsky's Syntactic Structures is amended with new articles in which leading figures of the field reflect on the impact of this seminal book on syntactic theory.

I would like to thank István Kenesei for providing the initial impetus for this collection. I am indebted to the contributors and the anonymous reviewers for their work and Acta Linguistica Academica for providing a forum for this celebratory issue.

Éva Dékány 


\section{References}

Emonds, Joseph E. and Jan Terje Faarlund. 2014. English: The language of the Vikings. Olomouc: Palacky University.

Hauser, Marc D., Noam Chomsky and W. Tecumseh Fitch. 2002. The faculty of language. What is it, who has it, and how did it evolve? Science 298. 1569-1579.

Hornstein, Norbert, Howard Lasnik, Pritty Patel-Grosz and Charles Yang (eds.). 2018. Syntactic structures after 60 years: The impact of the Chomskyan revolution in linguistics. Berlin \& Boston: Walter de Gruyter.

Kenesei, István (ed.). 2019. Nyelv, biológia, szabadság. A 90 éves Chomsky jelentősége a tudományban és azon túl [Language, biology, freedom. The importance of the 90-year-old Chomsky in science and beyond]. Gondolat: Budapest 
